DOI: https://doi.org/10.32839/2304-5809/2021-6-94-9

уДК 81'25

Ільченко Т.O.

Національний технічний університет «Харківський політехнічний інститут»

\title{
СУЧАСНІ ПРОБЛЕМИ ТА ТЕНДЕНЦІЇ ПЕРЕКЛАДУ МЕДИЧНОЇ ТЕРМІНОЛОГІЇ В УКРАЇНІ
}

\begin{abstract}
Анотація. Ця стаття присвячена дослідженню медичної перекладацької сфери. В нашій роботі проведено загальний огляд новітніх методів перекладання у галузі медицини і охорони здоров'я з метою ознайомлення з ними, адже протягом останніх років підходи до аналізу перекладу значно змінилися та з'явилось багато нових понять у сфері медицини, що вимагає від фрілологів, перекладачів та дослідників обізнаності з усіма новітніми тенденціями в ссрері медичного перекладу. Останнім часом це питання набирає актуальності серед дослідників та лінгвістів, адже в умовах сучасного світу все більше потрібні профресіонали, які спеціалізуються саме у медичній галузі. У процесі дослідження перекладацької діяльності, не можна не враховувати особливості медичної термінології, тому що медичний переклад - специфічний, потребуючий від перекладача цілковитої відповідальності, вид перекладацьких послуг. Переклад медичної документації має здійснювати лише обізнаний у щій сфері фрахівець, який знає їі особливості та впевнено оріентуеться у сучасних термінах медичного поприща.
\end{abstract}

Ключові слова: медична термінологія, переклад, інтерпретація, складені терміни, скорочення, абревіатури, англіцизм, грецизм, латинізм, епонім.

Ilchenko Tamara

National Technical University "Kharkiv Polytechnic Institute"

\section{THE MODERN TRANSLATION PROBLEMS AND TENDENCIES OF MEDICAL TERMINOLOGY IN UKRAINE}

Summary. The article is devoted to the research in the field of medicine and health care maintaining. It aims to provide an overview of the latest methods of medicine analysis of translating process in order to get acquainted with them, because over the past few years approaches to translating activity have changed significantly, requiring researchers, translators and philologists be aware of all the latest trends in the field of medicine translation. This issue has recently gained relevance among researchers and linguists, as the modern world increasingly needs professionals who specialise specifically in the healthcare field. During the process of researching translation activities, one cannot neglect the peculiarities of medical terminology, therefore medical translation is a specific type of translation requiring the translator to be fully responsible. Any medical documents should be translated only by a specialist translator who is knowledgeable in this subject matter and orientates masterfully when dealing with modern medical terminology. The terminological lexicon is not only widespread in science and technology, but also penetrates the common vocabulary of different social classes, especially medicine. The occurrence of a new vocabulary for the designation of medical concepts, reproducing the development of the latest English medical terminology system, represents a significant group of new word combination, which cause complications in the process of interrelationship of specialists in this field. The main focus of this paper relates to medical terms of translation process, and it is also worth paying attention to the importance of accuracy in medical and health care translation process. Consequently, the importance of training professionals who are experienced and qualified in the field of medicine and have a comprehensive level of knowledge of foreign languages remains as high as ever. The documentation translation concerning the medical history or the conclusion of performed analyses is directed to professionals who have a certain degree of education and a distinguished level of competence. The training of modern, highly qualified experts in the field of pharmacy and medicine who are fluent in foreign languages and prepared for international professional cooperation is one of the main challenges of today's education.

Keywords: medical terminology, translation, interpretation, compound terms, abbreviations, acronyms, English loan word, Graecism, Latin loan word and eponyms.

$\Pi$ остановка проблеми. Сьогодні науково-технічна термінологія постійно розвивається завдяки прогресу сучасного світу. Термінологічна лексика не тільки значно поширена в науці і техніці, але й проникае в розмовну мову різних соціальних класів, особливо медицини. Виникнення нової лексики для позначення медичних понять, що відтворюе розвиток новітньої англійської медичної термінологічної системи, представляе значну групу новоутворень, які завдають труднощі у процесі спілкування спеціалістів ціеї сорери.

Медична термінологія англійської мови, яка є предметом дослідження, постійно оновлюеться і перебуває у стані безперервного розвитку. Зростає асортимент закордонних лікарських препаратів, медичного обладнання, а також медичне устаткування дуже часто замінюеться новим i більш вдосконаленим. 3 кожним роком запроваджуються нові технології в медицині.

Дослідження особливостей медичної термінології та лексика науково-медичних текстів, а також інструкщій є актуальними на даний час, адже будь-яка помилка при перекладі може призвести до невірної інтерпретації отриманої інформації, що в майбутньому може стати причиною нещасного випадку або призвести до смерті пацієнта. 
Аналіз останніх досліджень та публікацій. Вивченням цієї досить актуальної галузі займається багато вітчизняних та іноземних дослідників, серед яких слід згадати профресора Гленна Флореса [4], Божену Джуганову [3], професорку Ханнелору Лі-Янке [5], Саймона Андрисена (керівник компанії, що спеціалізуеться на випробуваннях, проведених користувачами, і медичних перекладах) [1], Марії Плющ і т.д.

Виділення невирішених раніше частин загальної проблеми. Здійснивши аналіз попередніх досліджень, нами встановлено, що питання медичного перекладу та його впливу на перекладацьку діяльність у сфері медицини та охорони здоров'я все ще залишаються нерозглянутими в повній мірі та $є$ актуальними. Переклад в цій галузі охоплюе широкий спектр проблем. Саме відсутність глибинного і систематизованого дослідження перекладацького підходу при медичному перекладі обумовило необхідність багатопланового комплексного вивчення даної теми.

Формулювання цілей статті. Ця робота націлена на загальний огляд новітніх проблем та тенденцій перекладу медичної термінології у наукових лінгвістичних дослідженнях сфери охорони здоров'я, з метою ознайомлення з ними, адже протягом останніх років підходи до перекладацького аналізу тексту значно змінилися, що вимагае від мовознавців, перекладачів та дослідників обізнаності та досвіду у медичній cфері згідно з сучасними тенденціями в перекладознавстві. Адже переклад в медичній сфері характеризуеться специфічними особливостями, які $е$ актуальними для певного відрізку часу.

Виклад основного матеріалу. Переклад, безумовно, відіграе важливу роль у медицині: користування медичними послугами, результати досліджень, оприлюднення нових знахідок у міжнародному науковому співтоваристві та маркетинг нових лікарських засобів і приладів є ключовими ознаками цієї ролі [1]. Окремо від книги, статті та презентації, перекладені медичні тексти насамперед включають реестраційні документи, такі як заявки на реестрацію но- вих лікарських засобів та медичних препаратів, пристроїв, а також інструкції з експлуатації медичного обладнання та інструментів і документи для клінічних випробувань. Отже, перекладачі медичної сфери повинні мати значний досвід у перекладі в цій предметній області.

Під час комунікації в галузі охорони здоров'я зростає тенденція зосереджувати увагу на паціенті, і зараз загальновизнано, що існуе потреба в кваліфікованому перекладачеві для сприяння посередницької діяльності в міжмовній та міжкультурній сферах медичних установ, в результаті чого з'явилася низка перекладачів, які спеціалізуються саме в цій галузі.

Медичний переклад - специфічний, потребуючий від перекладача цілковитої відповідальності, вид перекладацьких послуг. Цим видом перекладу може займатися винятково спеціаліст 3 багатим досвідом перекладацької практики в галузі перекладу медичних документів, тому що помилка або неточність зі сторони спеціаліста можуть спричинити медичну похибку, результат якої важко спрогнозувати.

Переклад медичної документації має здійснювати лише обізнаний у цій сфері фрахівець, який знае її особливості та впевнено оріентуеться у сучасних термінах медичного поприща. У наш час до фохівців висуваються певні вимоги (рис. 1).

Окрім певних практичних навичок, перекладач повинен уміти використовувати профільну літературу, словники, довідники та додаткову інформацію. Подекуди доводиться навіть звертатися за консультацією до спеціалістів, а саме лікарів того чи іншого вузького профілю (хірурга, кардіолога, офтальмолога, невропатолога, рентгенолога, лікар-УЗД тощо), оскільки для здійснення цього виду діяльності потрібне повне осягнення змісту та ії цілковите розуміння.

Існуе помилкове уявлення, що переклад у сфері медицини найліпше здійснюють ті перекладачі, які не є фахівцями в галузі перекладу, маючи медичний ступінь або навіть практикуючі лікарі. Проте більш ніж декаду тому назад, дослідження Errors in Medical Interpretation and Their Potential Clinical Consequences in Pediatric
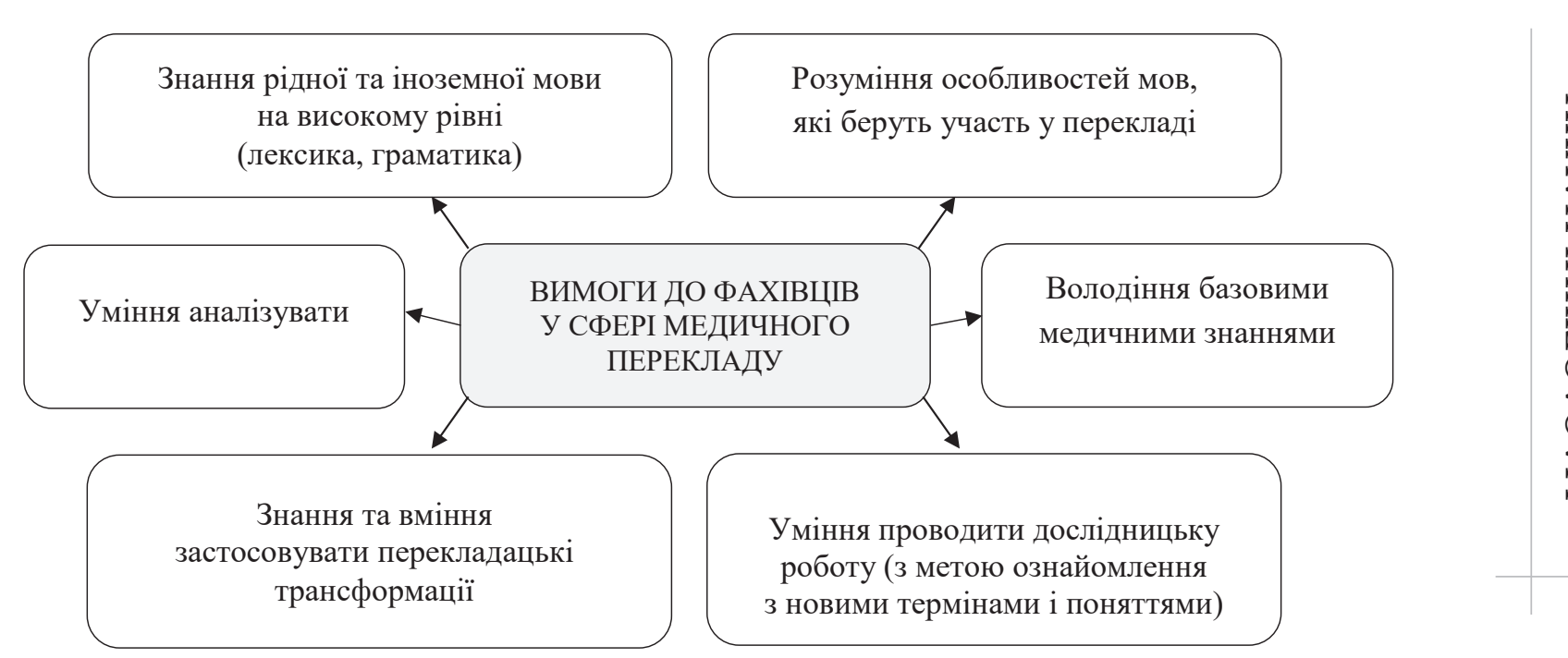

Рис. 1. Вимоги, що висуваються до фахівців у сфері перекладу медичних текстів 
Encounters, продемонструвало, що лікарі з профрільною освітою припускають майже $22 \%$ похибок, у той час як висококваліфрікований перекладач без медичної освіти допускає лише $12 \%$.

Основна увага в цій роботі приділяеться медичним термінам перекладу, також варто звернути увагу на значення точності під час перекладу в галузі медицини та охорони здоров'я. Гленн Флорес - відомий професор та лікар-педіатр написав численні новаторські статті медичної сфрери. У його публікаціях розглядається широкий спектр дослідницьких питань в охороні здоров'я, включаючи проблематику мовних бар'єрів у галузі медицини. За всю свою кар'єру Флорес здобув велику кількість нагород, і він $е$ радником багатьох організацій та бюро, а також генерального хірурга Інституту медицини та Центру 3 контролю та профілактики захворювань, США. Флорес вивчав інтерпретаційні помилки, їх частоту, категорії та потенційні клінічні наслідки. Його аналіз аудіозаписів та стенограм відвідувань в лікарняній амбулаторії показує, що помилок у медичній інтерпретащії зустрічається досить багато [4]. Середня кількість помилок становила 31 за сеанс, і 63\% усіх помилок мали потенційні клінічні наслідки. Помилки були розділені на наступні 5 категорій - опущення, додавання, заміна, редагування та хибне використання лексики:

1. Опущення: перекладач не інтерпретував слово / фрразу, вимовлену клініцистом, батьком чи дитиною.

2. Додавання: перекладач додав слово / фрразу до тлумачення, яке не було вимовлене клініцистом, батьком або дитиною.

3. Заміна: перекладач замінив слово / фрразу на різні слова / фррази, вимовлені клініцистом, батьком або дитиною.

4. Редагування: перекладач виклав свої власні особисті погляди як тлумачення слова / фррази вимовлені клініцистом, батьком або дитиною.

5. Хибне використання лексики: перекладач використав неправильний текст, фрразу, або слово, які не існують у цій конкретній мові. Аналіз виявляе, що найбільшу кількість помилок роблять випадкові посередники, які не навчені перекладу чи медицині, наприклад діти, інші члени сім'ї або медичний персонал лікарні.

Отже, потреба в підготовці спеціалістів, які досвідченні та компетентні в сорері медицини, а також знають іноземні мови на достатньому рівні, як і завжди залишається злободенною. Переклад текстового документу, який відноситься до історії хвороби або є висновком зі здійснених аналізів, направляється до продесіоналів, що мають певний ступінь освіти і високий кваліфікаційний рівень. За останній час медичні заклади вищої освіти влаштовують для своїх студентів проведення додаткових занять 3 більш поглибленого вивчення іноземних мов, окрім того, навчання в окремих інститутах проводиться на англійській, німецькій або інших мовах. Це надає змогу проводити підготовку для кваліфікованих спеціалістів-перекладачів. Підготовка сучасних висококваліфрікованих знавців у сфері фрармаціі та медицини, які володіють іноземними мовами і підготовлені до міжнародної профресійної співпраці є однією з найголовніших проблем сьогочасної освіти.
Продресорка Женевського університету (Швейцарія) Ханнелора Лі-Янке пропонуе чітку класифікацію труднощів медичного перекладу, яку можна застосувати до будь-яких мовних пар: 1) термінологічні проблеми; 2) труднощі перекладу скорочень; 3) труднощі перекладу епонімів; 4) допустимість застосування англіцизмів; 5) особливості сполучуваності мовних одиниць і структури тексту [5, с. 147-148]. Слід за Ханнелорою Лі-Янке виокремимо і розглянемо наступні найактуальніші перекладацькі труднощі у сорері медицини і охорони здоров'я сьогодення.

Ще 3 давніх часів виникали масштабні епідемії чуми і віспи, тифру та прокази. Розповсюдженню їх сприяли розвиток торгівельних взаємин 3 різноманітними країнами, пересування народних мас, пов'язаних з хрестовими походами, нагромадження населення в містах, затиснутих мурами фортець.

Сьогодні, наприклад, в часи пандемії зростає кількість інфекційних захворювань, таких як коронавірусна хвороба (COVID-19) - велика родина вірусів, які викликають захворювання, починаючи від звичайної застуди до більш важких занедужень. Ця хвороба, спричинена важким гострим респіраторним синдромом - коронавірусом 2 (SARS-CoV-2), має чіткий потенщіал для тривалої глобальної епідемії, високого рівня смертності та непрацездатності систем охорони здоров'я [6]. У зв'язку з цим виникає багато проблем та питань при перекладі скорочень та абревіатур, які останнім часом стали дуже популярними серед лікарів та використовуються навіть у медичному обладнанні при відображенні результатів обстеження (CDC - Centers for Disease Control, PUI - Person under investigation, PPE - personal protective equipment, WHO - World Health Organization). 3'явилося новітне обладнання для визначення діагнозів та ступеня важкості хвороби, написана та застосована значна кількість спеціальних електронних програм та додатків (Covid Symptom Study, formerly Covid Symptom Tracker - Великобританія; COVID-19 Apple / Google App, Private Kit: Safe Paths, CovidSafe, NOVID - CШA; OHIOH Framework - Німеччина; ROBERT ROBust and privacy-presERving proximity Tracing protocol Франція), що використовують цифрове відстеження для допомоги виявлення осіб, які могли контактувати з інфікованою COVID-19 людиною.

У період сьогодення, саме труднощі перекладу скорочень і термінологічні проблеми становляться дуже актуальними. Наприклад: SARSCoV-2 (Severe acute respiratory syndrome-related coronavirus 2) - коронавірус тяжкого гострого респіраторного синдрому-2, FFP mask - захисна фрільтруюча маска-респіратор, PCR test - тест полімеразної ланщюгової реакції, shelter-in-place ховайся, де ти є, stay-in-your-home - залишайся в себе вдома, Lockdown - локдаун та ін.

Ініціальні абревіатури дуже популярні в письмовій англійській мові для скорочення довгих описових термінів. Наприклад, біохімічні терміни, такі як: deoxyribonucleic acid - DNA (дезоксирибонуклеїнова кислота - ДНК), ribonucleic acid RNA (рибонуклеїнова кислота - РНК), adenosine triphosphate - ATP (аденозинтрифросdрат - ATФ); терміни клінічної медицини: acute lymphocytic leukaemia - ALL (гострий лімфобластний лей- 
коз - ГЛЛ), chronic lymphocytic leukaemia - CLL (хронічний лімфолейкоз - ХЛЛ), autoimmune thrombocytopenia - AITP (аутоімунна тромбоцитопенія - АТ). Відповідно, мовознавцям потрібно докласти зусиль, щоб охопити і опрацювати доволі вагомий пласт інформащії що стосуеться охорони і здоров'я людини.

Ще одним важливим видом термінів $є$ епоніми. Епонім - це термін, який містить у своєму складі власну назву, а також загальну назву на позначення наукового поняття. Під час дослідження медичних термінів - епонімів у медичній літературі ми часто натрапляли на думку, що епонімічні поняття є незручними у вживанні i викликають труднощі у процесі їх перекладу. Проте існує група епонімічних термінів. Які, врешті-решт, вкорінилися у медичній лексиці. Наприклад: antrum of Highmore (a natural cavity) - гайлорова пазуха (порожнина), pouch of Douglas - дугласовий простір, Linnartz's forcept - зажил Ліннартиа (для накладання ентероанастолоза), Museux's - зажил Мюзе та інші.

Особливістю медичної термінології є особливо широке вживання латинізмів і грецизмів. Також потрібно взяти до уваги останні зміни у зв'язку із впливом англо-американських наукових термінів. Англійська мова сильно подіяла і продовжуе впливати на наукову термінологію багатьох мов світу i, за допомогою цього втручання, багато термінів (деякі 3 них 3 латинського або грецького походження) були введені в українську та німецьку мови, як в спеціалізованих, так і в популярних дискурсах.

Наприклад, міжнародні грецькі / латинські терміни перекладено англійською: erythrocyte red blood cell (RBC); leukocyte - white blood cell (WBC); thrombocyte - blood platelet; monocyte mononuclear cell; haematopoiesis - blood cell production; coagulation-blood clotting; haemolysisblood destruction; haemostasis - arrest of bleeding. Переклади (кальки) грецьких / латинських термінів англійською мають різні стилістичні значення. У той час як міжнародні терміни erythrocytes, leukocytes, thrombocytes i coagulation слугують фрахівцям, їх англійські еквіваленти red blood cells, white blood cells, blood platelets i blood clotting використовуються в статтях чи промовах, націлених на звичайного читача або слухача.

Іноді разом з запозиченим терміном, виходить кілька варіантів перекладу, і вони взаємно утворюють синонімічних зв'язок, наприклад, erythrocyte red (blood) cell - red (blood) corpuscle; haematostasia control of haemorrhage - control of bleeding prevention of blood loss. Подібний синонімічний зв'язок існуе між такими термінами: Hodgkin's disease-Hodgkin's granuloma-Hodgkin's sarcoma; myeloproliferative syndrome - myeloproliferative disease i myeloproliferative disorder.

У минулому медична термінологія часто запозичувала медичні терміни 3 латині, проте, в даний час цей процес словотворення досить малопродуктивний. Запозичення 3 інших мов характерне для сучасного періоду. Велика кількість англійських наукових слів увійшли в обіг з фрранцузької мови [2].

Висновки. Отже, приймаючи до уваги все вищевказане, медична термінологія потребує чіткого і адекватного перекладу на українську мову 3 мови оригіналу. На жаль, в наш час не існує єдиних словників медичних термінів, у зв'язку з безперервним оновленням складу лексики, яке викликане прогресом в галузі медицини. Перекладачі та мовознавці України зустрічаються 3 певними труднощами медичного перекладу.

Фахівець повинен не лише вільно володіти лексикою конкретної тематики, а й розбиратися в поняттях та термінах. Абсолютна точність і відсутність двозначного тлумачення - найважливіша особливість перекладу.

Перспективою подальшого дослідження $\epsilon$ створення бази даних онлайн-словників медичної термінології за призначенням (інструкції, лікарські препарати, медичне устаткування). Усе це дозволить не лише систематизувати термінологію, маючи швидкий доступ до ресурсів, але й спростити перекладацьку діяльність.

\section{Список літератури:}

1. Andriesen S. Quality Control in Medical Translations. Innovations in Pharmaceutical Technology. 2008. Vol. 14(2). P. 36-49.

2. Chabner D.E. The Language of Medicine. New York : W. B. Saunders Company, 1996

3. Dzuganova B. English Medical terminology - different ways of forming medical terms. JAHR. 2013. Vol. 4 . № 7. P. 55-69.

4. Flores G. Errors in Medical Interpretation and their Potential Clinical Consequences in Pediatric Encounters. Pediatrics. 2003. Vol. 111. P. 6-14.

5. Lee-Jahnke H. L'enseignement de la traduction médicale: un double défi? Meta: Journal des traducteurs. 2001. Vol. 46. No 1. P. 145-153.

6. Quantifying SARS-CoV-2 transmission suggests epidemic control with digital contact tracing. URL: https://science.sciencemag.org/content/368/6491/eabb6936

\section{References:}

1. Andriesen S. (2008) Quality Control in Medical Translations. Innovations in Pharmaceutical Technology, vol. 14(2), pp. 36-49.

2. Chabner D.E. (1996) The Language of Medicine. New York: W. B. Saunders Company.

3. Dzuganova B. (2013) English Medical terminology. Different ways of forming medical terms, vol. 4, no. 7, pp. 55-69. (in Russian)

4. Flores G. (2003) Errors in Medical Interpretation and their Potential Clinical Consequences in Pediatric Encounters. Pediatrics, vol. 111, pp. 6-14.

5. Lee-Jahnke H. (2001) L'enseignement de la traduction médicale: un double défi? Meta: Journal des traducteurs. vol. 46, no. 1, pp. 145-153.

6. Quantifying SARS-CoV-2 transmission suggests epidemic control with digital contact tracing. URL: https://science.sciencemag.org/content/368/6491/eabb6936 